\title{
Services Linkages and the Value Added Content of Trade
}

\author{
Joseph Francois ${ }^{1}$, Miriam Manchin ${ }^{2}$ and Patrick Tomberger ${ }^{3}$ \\ ${ }^{1}$ University of Bern, Bern, Switzerland and CEPR, London, UK, ${ }^{2}$ University College London, London, \\ $U K$, and ${ }^{3}$ Johannes Kepler Universität Linz, Linz, Austria
}

\section{INTRODUCTION}

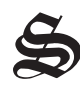
ERVICES are an important feature of the global economic landscape, a feature whose relevance follows in part from intermediate linkages between services and production. The gross value of cross-border services trade in 2011 was $\$ 3.4$ trillion, 18.6 per cent of total world trade in both goods and services. This share rises to almost 50 per cent when transactions are measured in terms of the direct and indirect value added content of trade - that is, measured in terms of the activities embodied in final products for export instead of being measuring in terms of the gross value of exports by final category crossing borders (Escaith, 2008). With increased globalisation of services, growth of delivery by multinational enterprises through affiliates has also been dramatic (Christen and Francois, 2015). If we add the sales of services by foreign affiliates of multinational firms (also known as establishment trade) to cross-border trade, then the value of international transactions in services rises still further. Data for 15 OECD countries alone put the value of establishment trade at $\$ 1.5$ trillion in 2007 (World Trade Organization, 2009).

Productivity trends in services have been a basic determinant of recent growth in the OECD, while changes in global and regional sourcing by multinational firms have led to increasingly complex patterns of trade in intermediate goods and services passing within and between countries before reaching final consumers. Working with the EU-KLEMS database, Inklaar et al. (2008) find rising investment in information and communications technology (ICT) and growth in human capital were both important drivers of labour productivity in commercial services in Europe, although there are marked differences across countries and sectors. How well this translated into overall productivity growth helps to explain overall differences in performance across Europe. Francois and Woerz (2008), mapping measures of Leontief-based direct and indirect service intensity to production and productivity indicators, find that service sector openness has boosted the competitiveness of more technology and skill-intensive industry in the OECD, at the expense of less ICT and skill-intensive sectors. Evidence linking services trade to the increasing complexity of production, what Baldwin (2006, 2014) has labelled the second unbundling, includes Johnson and Noguera (2012a) and Johnson and Noguera (2012b), Baldwin and Lopez-Gonzalez (2014), and Egger et al. (2015). ${ }^{1}$

\footnotetext{
All views expressed in this paper are strictly those of the authors and do not reflect the official views or positions of any institution with which they may be affiliated, or of anyone at those institutions. We acknowledge support for this research from the World Bank and from the Swiss NCCR Trade Regulation.

1 See Francois and Hoekman (2010) for an overview of the evolving literature on services trade, and distinctions drawn with respect to goods trade, as well as Egger et al. (2015) for an overview of the literature on the importance of services in supporting unbundling.
} 
In this paper, we examine the changing role of services as inputs in the structure of global production and trade from 1992 to 2011, highlighting both the direct and indirect contribution of services to value added in exports. Our panel of global input-output data (a set of global social accounting matrices spanning intermittent years from 1992 to 2011) covers not only key OECD economies, but also a range of developing countries. The length and breadth of the panel allow us to trace more long-run patterns, and focus on a border range of countries, than the existing literature. ${ }^{2}$ We examine the structure of services embodied in trade on a value added basis, providing new insights about trends over the time span covered.

In terms of patterns over time, our results serve to highlight the importance of non-traded services in trade, and how this has evolved since the early 1990s. The ratio of value added to gross trade values has been falling for goods since 1992, consistent with the now common observation that production chains for goods have become more complex, with embodied value added sometimes crossing borders many times. However, it turns out that this same pattern can also be seen for services. Yet there is a marked difference with respect to goods. In goods sectors, the value added contained in trade, even when we account for linkages and indirect exports, is substantially less than the gross value of exports. Due to vertical chains of production, the same value added is exported several times before final sale. In services, however, indirect exports (through forward linkages) are far more important than direct exports. As a result, indirect exports, on a value added basis, are consistently greater than the value of gross exports. However, as service tradability has increased since the early 1990s, for some service sectors this ratio has been falling, although it is still well above the pattern observed for goods.

Focusing on the cross-country dimension, we find that more developed countries tend to have more service-intensive exports. In all countries, taking into account also intermediate linkages, the service sector is critical to both the overall cost structure and competitiveness of goods, and to the more general economic performance of countries. This highlights that a well-functioning, competitive service sector not only is important for the export performance of the service sector, but crucially determines the export performance of the manufacturing sector as well. Thus, one needs to understand service sector policies when assessing determinants of competitiveness in goods sectors.

We have organised the paper as follows. Section 2 discusses concepts for the measurement of value added intensity, as well as our data. Section 3 focuses on how services trade has evolved globally, and how this differs from goods. Section 4 then discusses data issues at a country level. This is followed by closing remarks in Section 5 .

\section{CONCEPTS AND DATA}

We work with multiple versions of the Global Trade Analysis Project (GTAP) database, benchmarked to 1992, 1995, 1997, 2001, 2004, 2007 and 2011. These data represent a form of social accounting data - a variation on the social accounting matrix or SAM - where incomes or receipts are shown in the rows of the SAM while expenditures or outlays are shown in the columns. The basic structure of the GTAP data set is well documented

\footnotetext{
${ }^{2}$ Earlier cross-country comparisons, often based on GTAP data, include Park and Chan (1989), Uno (1989) and Francois and Reinert (1996). Francois and Woerz (2008) also work with earlier versions of the GTAP database, though with more emphasis on the impact of policy on services linkages to production.
} 
(McDougall, 2001; McDougall and Hagemejer, 2005). The database itself is produced by a long-standing global research consortium that includes the World Bank, the European Commission, US International Trade Commission, the World Trade Organization, the OECD, the United Nations Conference on Trade and Development (UNCTD), the Food and Agriculture Organization (UNFAO), and a number of universities and research institutes. The data reflect a massive combined effort to produce a shared public good - a database of national inputoutput tables, organised as social accounting data, linked to each other through trade and investment flows, and supplemented by satellite data on emissions, trade policies, resource usage and such. It stands as a critical, open-source input to applied policy modelling, ranking from climate change to regional trade agreements and food security. Over time, the data set has grown to include more countries and more sectors (Hertel, 2013). To maintain backward compatibility, we start with the 1992 structure of regions and sectors and carry this forward in aggregations of more recent iterations of the data set. This structure is detailed in Table 1 .

While national service flows are based on national input-output data, the data on services trade flows in our database come from a number of sources. The OECD, Eurostat and the UN all provide data in some form on bilateral services trade flows (both imports and exports) by partners and balance of payments sectors (BOPs) for up to 24 sectors and subsectors. UN data present the most comprehensive coverage of reporting countries among the three sources and at present provide data on roughly 190 reporters. Eurostat and OECD provide data for a more limited number of reporters, though with more sector detail than the UN. Eurostat covers 27 EU members plus Croatia, Iceland, Japan, Norway, Turkey, Switzerland and USA, while the OECD covers 28 countries (all the OECD members apart from Chile, Iceland, Israel, Slovenia and Switzerland). Time coverage is the deepest with Eurostat and US source data. IMF data cover almost as many countries as the UN, and for a longer time span, but only for trade with world. ${ }^{3}$ Within GTAP, the efforts to reconcile services balance of payments data with national input-output data are well documented and reflect innovative approaches based on information theory and entropy methods to flesh out the pattern of trade enough to allow construction of a global data set for estimating cross-border trade in services (McDougall and Hagemejer, 2005; Van Leeuwen and Lejour, 2006). For the transport sector, reconciliation of trade data is explicitly linked to the parallel reconciliation of data on trade in goods, as services play a critical role in bridging the gap between reported export flows for goods, in one country's national accounts data, and reported import flows in another country's data (Gehlhar, 1996).

The final structure given to the data provides a comprehensive and consistent record of national income accounting relationships between different sectors and regions. It is based on a fundamental, general equilibrium principle of economics - every income (receipt) has a corresponding expenditure (outlay). The strength of this framework is that it provides a comprehensive and consistent record of the interrelationships of an economy, including intermediate and final demand linkages. For our purposes, it offers the advantage of linking consumption and external trade patterns explicitly to the inter-industry structure of intermediate demand. This allows for a fuller analysis than is possible when working strictly with raw input-output tables alone.

To generate these values, we begin by denoting a representation of intermediate and final demand as follows:

\footnotetext{
${ }^{3}$ See Francois and Pindyuk (2010).
} 


$$
Y=Z-A Z \text {. }
$$

In equation (1), the term $\boldsymbol{Y}$ denotes a final demand vector, $\boldsymbol{Z}$ denotes a gross output vector, and $\boldsymbol{A}$ denotes a matrix of intermediate use coefficients. Equation (1) therefore defines final output with respect to intermediate input requirements. With some manipulation, we arrive at the Leontief inverse matrix, also known as the multiplier matrix $\boldsymbol{M}$ :

TABLE 1

Regions and Sectors

\begin{tabular}{ll}
\hline Regions & Sectors \\
\hline Australia & Agr, Forestry, Fisheries \\
New Zealand & Processed Foods \\
Japan & Energy Extraction \\
Korea & Minerals nec \\
Indonesia & Beverages and Tobacco Products \\
Malaysia & Textiles \\
Philippines & Wearing Apparel \\
Singapore & Leather Products \\
Thailand & Wood Products \\
China & Paper Products, Publishing \\
Hong Kong & Chemical, Rubber, Plastic Products \\
Taiwan & Mineral Products nec \\
India & Ferrous Metals \\
Rest of South Asia & Metals nec \\
Canada & Metal Products \\
United States & Transport Equipment \\
Mexico & Machinery and Equipment nec \\
Central America, Caribbean & Manufactures nec \\
Argentina & Electricity, Gas, Water \\
Brazil & Construction \\
Chile & Trade and Transport Services \\
Rest of South America & Other Private Services \\
European Community 12 & PubAdmin/Defence/Health/Educat \\
Austria, Finland, Sweden & Dwellings \\
new EU-12 Members & \\
Former Soviet Union & \\
Rest of Middle East & \\
Rest of sub-Saharan Africa & \\
Rest of World & \\
\hline & \\
\hline & \\
\hline
\end{tabular}

Notes:

Composite regions:Rest of South Asia: Afghanistan, Bangladesh, Bhutan, Maldives, Nepal, Pakistan, Sri Lanka; Cent. America, Carib.: Belize, Costa Rica, El Salvador, Guatemala, Honduras, Nicaragua, Panama, Cuba, Dominica, Dominican Rep., Haiti, Jamaica, Puerto Rico, Trinidad a. Tobago, Carib. small islands; rest of S. America: Bolivia, Colombia, Ecuador, Guyana, Paraguay, Peru, Suriname, Uruguay, Venezuela; EC 12: Belgium, Denmark, France, Germany, Greece, Ireland, Italy, Luxembourg, Netherlands, Portugal, Spain, United Kingdom; new EU 12 Members: Bulgaria, Cyprus, Czech Republic, Estonia, Hungary, Latvia, Lithuania, Malta, Poland, Romania, Slovakia, Slovenia; former Soviet Union: Armenia, Azerbaijan, Belarus, Georgia, Kazakhstan, Kyrgyzstan, Moldova, Russia, Tajikistan, Turkmenistan, Ukraine, Uzbekistan; rest of Middle East: Bahrain, Iran, Iraq, Israel, Jordan, Kuwait, Lebanon, Oman, Qatar, Saudi Arabia, Syria, Turkey, United Arab Emirates, Yemen; rest of sub-Saharan Africa: Angola, Benin, Botswana, Burkina Faso, Burundi, Cameroon, Cape Verde, Central African Republic, Chad, Comoros, Republic of Congo, Democratic Republic of Congo, Djibouti, Equ. Guinea, Eritrea, Ethiopia, Gabon, Gambia, Ghana, Guinea, Guinea-Bissau, Ivory Coast, Kenya, Lesotho, Liberia, Madagascar, Malawi, Mali, Mauritania, Mauritius, Mayotte, Mozambique, Namibia, Niger, Nigeria, Rwanda, Sao Tome/Prin., Senegal, Seychelles, Sierra Leone, Somalia, S. Africa, Sudan, Swaziland, Tanzania, Togo, Uganda, Zambia, Zimbabwe. 


$$
\boldsymbol{Z}=(\boldsymbol{I}-\boldsymbol{A})^{-1} \boldsymbol{Y}=\boldsymbol{M} \boldsymbol{Y} .
$$

The multiplier matrix $\boldsymbol{M}$ measures the inputs contained in a unit of final output. In particular, if we assign the sector indexes $i, j$ to the $\boldsymbol{A}$ and $\boldsymbol{M}$ matrices, then a representative element of the $\boldsymbol{M}$ matrix, $M_{i, j}$, gives the direct and indirect inputs (and thus the sector $i$ receipts) linked to each unit (e.g. each dollar) of sector $j$ receipts in the data. ${ }^{4}$ This implies real production activities measured by value of output. For our purposes, it provides a means to trace, through these income flows, the flow of gross activity and value added from intermediate to final goods and services, ostensibly across borders as well as sectors. Because linkages will vary by industry, each industry will be characterised by different multipliers. To focus on value added, we note first that in terms of gross output values $\boldsymbol{Z}$, some share of this involves value added within each sector. We define $\hat{\boldsymbol{B}}^{5}$ as the diagonal matrix indexed over $i, j$ with diagonal elements equal to the value added shares of output $\boldsymbol{Z}$. We then use $\boldsymbol{M}$ to provide a breakdown of the flow of value added across activities in the form of the matrix $\boldsymbol{V}$ :

$$
\boldsymbol{V}=\hat{\boldsymbol{B}} \boldsymbol{M} .
$$

Similar to the Leontief inverse matrix itself, the $\boldsymbol{V}$ matrix identifies the inputs of value added in each sector related to a unit of final demand. If we multiply $\boldsymbol{V}$ by the diagonal matrix $\hat{\boldsymbol{Y}}$, whose non-zero elements are the vector of final output, the matrix yields a breakdown of economywide value added (the primary component of gross national product on a source basis). Similarly, if we multiply $\boldsymbol{V}$ by the diagonal matrix $\hat{\boldsymbol{X}}$, whose non-zero elements are the national export vector, we can recover the value added content of exports (both direct and indirect):

$$
\begin{aligned}
\boldsymbol{G} & =\boldsymbol{V} \hat{\boldsymbol{Y}}, \\
\boldsymbol{H} & =\boldsymbol{V} \hat{\boldsymbol{X}} .
\end{aligned}
$$

The $\boldsymbol{G}$ matrix and the $\boldsymbol{H}$ matrix give us the set of linkages, both direct and indirect, between value added across sectors. Assigning sector indices $i, j$ again, then following the rows of matrices $\boldsymbol{G}_{i, j}$ and $\boldsymbol{H}_{i, j}$, allows us to follow direct and indirect value added of a given sector $i$ to other sectors $j$. We refer to these flows as forward linkages. Following the columns of matrices $\boldsymbol{G}_{i, j}$ and $\boldsymbol{H}_{i, j}$ allows us to assess the direct and indirect value added ending up in a given sector $j$ from upstream activities in sectors $i$. Summing up over rows (columns) of $\boldsymbol{G}_{i, j}$ and $\boldsymbol{H}_{i, j}$ gives then the total direct and indirect value added based on forward (backward) linkages contained in the exports or final sales of sector $i(j)$.

\section{GLOBAL PATTERNS OF PRODUCTION AND TRADE}

We start with the pattern of global production and trade. In this case, we have collapsed all regions to a single region, keeping the sectors defined as in Table 1. We also preserve the flow of trade (exports and imports) for this aggregate world, so that we can examine at a global level the properties of trade flows in terms of direct and indirect value added (considering

\footnotetext{
${ }^{4}$ In multiplier analysis with fixed input coefficients, these values also represent fixed unit input requirements in value terms, although of course in CGE models one can allow for these coefficients to be endogenous.

${ }^{5}$ We indicate diagonal matrices by a circumflex.
} 
FIGURE 1

Value Added in Exports Relative to Gross Value of Exports

Total VA in Exports Relative to Gross Export Value
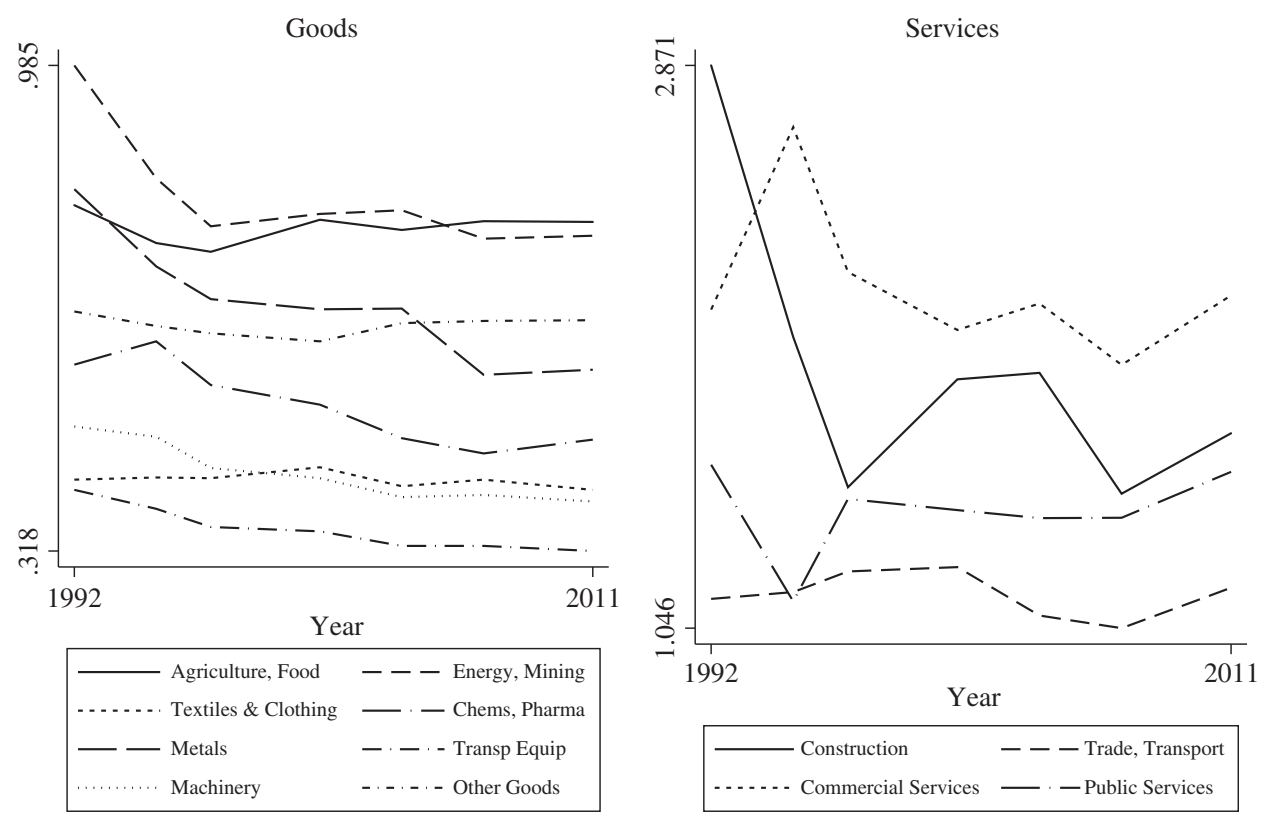

Note:

Figure shows the total value added (based on forward linkages) contained in the exports of a sector divided by the gross value of this sector's exports

forward linkages), and the share of services in the cost of traded goods. We will then carry forward the same approach, examining relative gross and value added flows, and the relevance of linkages to specific sectors, at individual country level in the subsequent section.

The ratio of total value added (based on forward linkages) in exports relative to the gross value of exports is reported in Figure 1. The ratio for a sector corresponds to $\sum_{j} \boldsymbol{H}_{i, j} / \sum_{j} \hat{\boldsymbol{X}}_{i, j}{ }^{6}$. For the world as a whole, there has been a discernible drop in the value added content of exports, relative to gross exports, since 1992. This fits with the theme, common to the value chain literature and to explanations of the collapse in trade during the Great Recession, that the global subdivision of labour, and the resulting increased roundaboutness of production, means we are double-counting value added when we look at gross trade values. As production fragments vertically along geographic lines, this should lead to a fall in this ratio.

There are identifiable differences across sectors. On the low end, trade in machinery, transport equipment, and textiles and clothing all have value added contents less than 41 per cent of the gross trade values as of 2011. These drops are between 2 and 10 percentage points since 1992. To put this into perspective, this means that for every $\$ 100$ in global gross exports in machinery in 1992, there was $\$ 49.40$ in value added. By 2011, this had dropped to $\$ 38.60$, a drop of 20 per cent in the value added content of trade in this sector. For transport

\footnotetext{
${ }^{6}$ Since $\hat{\boldsymbol{X}}$ is a diagonal matrix, instead of row sums also column sums could be used.
} 
equipment, the drop is from $\$ 40.50$ to $\$ 32.30$, or a 22 per cent drop in the value added content of trade.

The pattern is quite different when we focus on services sectors. A first point to note in Figure 1 is that the ratio of value added to gross exports is consistently greater than 1 . This means that most exports in services, on a value added basis, are embodied in exports of goods. Direct exports in services are small globally, relative to indirect or embodied exports. Another point to note is that this ratio is more volatile for services. It has decreased for construction and commercial services until 1997, after then it stayed stable until 2011 as it is the case for public services and trade and transport over the whole period. So although trade in services has grown rapidly, so has trade in goods. With the exception of construction, where there has been substantial growth in direct exports, the basic pattern is one of the embodied exports dominating direct exports, and relative stability in this pattern in the 1992-2011 period.

We turn next to the basic composition of trade for the world as a whole, adjusted to measure the value added content of trade. We report these in Table 2 (for forward linkages) and Table 3 (for backward linkages). The basic pattern is again one of stability in the relative importance of services trade globally, whether measured on a gross (sector shares of gross exports are presented in Table A2 in the Appendix) or net basis. On the goods side, chemicals and metals account for an increasing share of total trade in value added, while the share devoted to transport and trade services has fallen consistently. Interestingly, public services (including education and health care) account for a rising share of embodied trade. Where one has more detailed data on these sectors (from EU-KLEMS for example), this may point to a path for promising research quantifying the impact of rising health costs on cost structures as reflected in the value added content of trade.

While most of the discussion in this paper is focused on forward linkages, in Table 3, we have focused instead on backward linkages. This way of calculating value added takes into account all the value added from other sectors which went into a given sector. In other words, when we focus on actual exports of metals or transport equipment or chemicals and recognise that these embody value added from upstream activities, what is the value added content of exports, on a sector basis? The most important sector is machinery at 19.8 per cent, a share that has slightly decreased from 1992 to 2011. Collectively, machinery, transport equipment, metals and chemicals account for 45 per cent of all exports, on a value added basis. If we compare the values in Table 2 with those in Table 3, it is clear that a large share of total value added, in the goods sectors that dominate trade on a gross value basis, comes from service inputs to manufacturing. Now we turn from the global to the individual perspective and discuss the value added content of trade for a subset of representative countries.

\section{SERVICES AT COUNTRY AND REGION LEVEL}

We now turn to an analysis of individual countries and regions. This means that rather than working with globally aggregated social accounting data, we have now subdivided all flows by region. We will not explore bilateral linkages pertaining to services here but will instead focus on individual subsets of our social accounts data, region by region, with external accounts in each case aggregated to a rest of world.

Table 4 presents a cross-section of services share of exports on a gross value, direct value added and total domestic value added (forward linkages) basis for 1992 and 2011. This allows us to assess the importance of services exports between countries also over our sample period. Two patterns are apparent. One is that certain economies (the United States, Hong Kong, 
TABLE 2

Sector Shares of Total Value Added in Exports World Trade Shares Based on Forward Linkages

\begin{tabular}{|c|c|c|c|c|c|c|c|}
\hline & 1992 & 1995 & 1997 & 2001 & 2004 & 2007 & 2011 \\
\hline Agr., forestry, fisheries & 0.057 & 0.053 & 0.046 & 0.045 & 0.043 & 0.041 & 0.053 \\
\hline Processed food & 0.015 & 0.021 & 0.020 & 0.020 & 0.020 & 0.020 & 0.023 \\
\hline Energy extraction & 0.100 & 0.058 & 0.061 & 0.060 & 0.091 & 0.116 & 0.096 \\
\hline Minerals nec & 0.016 & 0.013 & 0.009 & 0.008 & 0.013 & 0.016 & 0.023 \\
\hline Beverages, tobacco & 0.005 & 0.005 & 0.006 & 0.006 & 0.005 & 0.005 & 0.005 \\
\hline Textiles & 0.017 & 0.018 & 0.019 & 0.020 & 0.016 & 0.014 & 0.015 \\
\hline Wearing apparel & 0.012 & 0.012 & 0.011 & 0.011 & 0.009 & 0.007 & 0.007 \\
\hline Leather products & 0.006 & 0.007 & 0.006 & 0.006 & 0.005 & 0.005 & 0.005 \\
\hline Wood products & 0.010 & 0.011 & 0.011 & 0.011 & 0.011 & 0.010 & 0.009 \\
\hline Paper, publishing & 0.027 & 0.027 & 0.025 & 0.024 & 0.021 & 0.019 & 0.019 \\
\hline Chemicals, rubber, plastic & 0.057 & 0.075 & 0.067 & 0.069 & 0.072 & 0.069 & 0.081 \\
\hline Mineral products & 0.009 & 0.011 & 0.015 & 0.015 & 0.010 & 0.010 & 0.011 \\
\hline Ferrous metals & 0.021 & 0.024 & 0.020 & 0.018 & 0.020 & 0.020 & 0.022 \\
\hline Metals nec & 0.012 & 0.012 & 0.014 & 0.013 & 0.014 & 0.016 & 0.020 \\
\hline Metal products & 0.022 & 0.023 & 0.022 & 0.022 & 0.025 & 0.024 & 0.023 \\
\hline Transport equipment & 0.044 & 0.043 & 0.044 & 0.048 & 0.047 & 0.045 & 0.042 \\
\hline Machinery, equipment nec & 0.130 & 0.146 & 0.147 & 0.145 & 0.126 & 0.118 & 0.115 \\
\hline Manufactures nec & 0.014 & 0.014 & 0.014 & 0.017 & 0.012 & 0.012 & 0.013 \\
\hline Construction & 0.007 & 0.010 & 0.011 & 0.010 & 0.012 & 0.012 & 0.012 \\
\hline Electricity, gas, water & 0.024 & 0.027 & 0.024 & 0.031 & 0.028 & 0.029 & 0.023 \\
\hline Trade and transport & 0.203 & 0.191 & 0.180 & 0.172 & 0.146 & 0.140 & 0.147 \\
\hline Trade & n.a. & n.a. & 0.082 & 0.085 & 0.069 & 0.067 & 0.069 \\
\hline Transport & n.a. & n.a. & 0.092 & 0.080 & 0.071 & 0.065 & 0.071 \\
\hline Other commercial services & 0.175 & 0.162 & 0.197 & 0.198 & 0.224 & 0.224 & 0.211 \\
\hline Communication & n.a. & n.a. & 0.017 & 0.018 & 0.018 & 0.018 & 0.017 \\
\hline Financial services & n.a. & n.a. & 0.034 & 0.034 & 0.039 & 0.041 & 0.041 \\
\hline Insurance & n.a. & n.a. & 0.009 & 0.008 & 0.009 & 0.009 & 0.008 \\
\hline Business services & n.a. & n.a. & 0.105 & 0.105 & 0.143 & 0.142 & 0.132 \\
\hline Recreation, other services & n.a. & n.a. & 0.034 & 0.033 & 0.015 & 0.014 & 0.014 \\
\hline Public services & 0.013 & 0.033 & 0.030 & 0.029 & 0.027 & 0.024 & 0.022 \\
\hline Dwellings & 0.005 & 0.006 & 0.002 & 0.002 & 0.003 & 0.003 & 0.003 \\
\hline Total & 1.000 & 1.000 & 1.000 & 1.000 & 1.000 & 1.000 & 1.000 \\
\hline
\end{tabular}

Notes:

(i) Table shows total value added (based on forward linkages) contained in the exports of a sector divided by the total value added contained in global trade for the years 1992-2011.

(ii) The shares are calculated as $\sum_{j} \boldsymbol{H}_{i, j} / \sum_{i} \sum_{j} \boldsymbol{H}_{i, j}$.

Singapore and Europe) stand out as commercial services exporters. Lower income countries, at least in terms of gross exports, are further down the ladder of relative importance in services exports. The development of Hong Kong is remarkable as it increased its share of exported gross services from 3.5 per cent in 1992 to almost 20 per cent in 2011. Singapore, while still among the top services exporters in 2011, experienced a considerable decrease in the share of such exports by over 10 per cent since the beginning of the 1990s. The United States and the Western European EU member states as a whole moderately increased their gross services exports during our sample period, with the exception of the EU-3 (Austria, Sweden and Finland), which became less important services exporters according to that measure. 
TABLE 3

Sector Shares of Total Value Added Exports World Trade Shares Based on Backward Linkages

\begin{tabular}{|c|c|c|c|c|c|c|c|}
\hline & 1992 & 1995 & 1997 & 2001 & 2004 & 2007 & 2011 \\
\hline Agr., forestry, fisheries & 0.045 & 0.039 & 0.033 & 0.031 & 0.027 & 0.025 & 0.033 \\
\hline Processed food & 0.032 & 0.043 & 0.040 & 0.037 & 0.039 & 0.038 & 0.046 \\
\hline Energy extraction & 0.083 & 0.055 & 0.061 & 0.059 & 0.088 & 0.117 & 0.099 \\
\hline Minerals nec & 0.018 & 0.015 & 0.006 & 0.006 & 0.011 & 0.015 & 0.023 \\
\hline Beverages, tobacco & 0.009 & 0.008 & 0.009 & 0.008 & 0.008 & 0.007 & 0.008 \\
\hline Textiles & 0.023 & 0.024 & 0.027 & 0.025 & 0.024 & 0.020 & 0.022 \\
\hline Wearing apparel & 0.022 & 0.023 & 0.020 & 0.021 & 0.017 & 0.016 & 0.017 \\
\hline Leather products & 0.012 & 0.013 & 0.011 & 0.012 & 0.009 & 0.009 & 0.010 \\
\hline Wood products & 0.017 & 0.018 & 0.017 & 0.018 & 0.017 & 0.015 & 0.014 \\
\hline Paper, publishing & 0.022 & 0.026 & 0.022 & 0.022 & 0.020 & 0.017 & 0.017 \\
\hline Chemicals, rubber, plastic & 0.076 & 0.091 & 0.086 & 0.091 & 0.103 & 0.099 & 0.114 \\
\hline Mineral products & 0.009 & 0.011 & 0.017 & 0.017 & 0.011 & 0.010 & 0.010 \\
\hline Ferrous metals & 0.021 & 0.026 & 0.022 & 0.019 & 0.023 & 0.025 & 0.024 \\
\hline Metals nec & 0.014 & 0.016 & 0.022 & 0.020 & 0.022 & 0.027 & 0.031 \\
\hline Metal products & 0.016 & 0.018 & 0.018 & 0.018 & 0.019 & 0.019 & 0.020 \\
\hline Transport equipment & 0.089 & 0.084 & 0.088 & 0.094 & 0.095 & 0.087 & 0.081 \\
\hline Machinery, equipment nec & 0.208 & 0.229 & 0.238 & 0.233 & 0.213 & 0.193 & 0.198 \\
\hline Manufactures nec & 0.024 & 0.022 & 0.022 & 0.026 & 0.017 & 0.017 & 0.018 \\
\hline Construction & 0.002 & 0.004 & 0.006 & 0.004 & 0.005 & 0.007 & 0.005 \\
\hline Electricity, gas, water & 0.001 & 0.002 & 0.004 & 0.004 & 0.004 & 0.005 & 0.004 \\
\hline Trade and transport & 0.160 & 0.144 & 0.126 & 0.117 & 0.108 & 0.104 & 0.098 \\
\hline Trade & n.a. & n.a. & 0.024 & 0.029 & 0.025 & 0.024 & 0.020 \\
\hline Transport & n.a. & n.a. & 0.096 & 0.080 & 0.075 & 0.071 & 0.071 \\
\hline Other commercial services & 0.091 & 0.065 & 0.087 & 0.098 & 0.105 & 0.113 & 0.095 \\
\hline Communication & n.a. & n.a. & 0.006 & 0.007 & 0.007 & 0.008 & 0.007 \\
\hline Financial services & n.a. & n.a. & 0.007 & 0.010 & 0.013 & 0.018 & 0.015 \\
\hline Insurance & n.a. & n.a. & 0.007 & 0.007 & 0.010 & 0.009 & 0.008 \\
\hline Business services & n.a. & n.a. & 0.055 & 0.061 & 0.062 & 0.067 & 0.056 \\
\hline Recreation, other services & n.a. & n.a. & 0.013 & 0.014 & 0.012 & 0.011 & 0.010 \\
\hline Public services & 0.008 & 0.026 & 0.019 & 0.019 & 0.017 & 0.016 & 0.013 \\
\hline Dwellings & 0.000 & 0.000 & 0.000 & 0.000 & 0.000 & 0.000 & 0.000 \\
\hline Total & 1.000 & 1.000 & 1.000 & 1.000 & 1.000 & 1.000 & 1.000 \\
\hline
\end{tabular}

Notes:

(i) Table shows total value added (based on backward linkages) contained in the exports of a sector divided by the total value added contained in global trade for the years 1992-2011.

(ii) The shares are calculated as $\sum_{i} \boldsymbol{H}_{i, j} / \sum_{i} \sum_{j} \boldsymbol{X}_{i, j}$.

An exception among developing countries is India, which has the highest share of commercial services exports on a gross basis among the developing nations, even surpassing Europe and the United States. Also, over the sample period India had one of the highest increases in gross exports of services, only second to Hong Kong. The opposite development can be seen for other countries in the region, though. Having considerable high shares of services exporters on a gross value basis in 1992, this share decreased for countries such as Taiwan, the Philippines and the rest of South Asian region between 6 and 14 per cent. Also mainland China experienced such a decrease, but at moderate 2 per cent.

The second pattern arises from the fact the real importance of services exports is underestimated relative to manufacturing exports when those exports are valued at gross values. This 
TABLE 4

Services Share of Exports in 1992 and 2011

\begin{tabular}{|c|c|c|c|c|c|c|}
\hline \multirow[b]{2}{*}{ Australia } & \multicolumn{2}{|c|}{$\begin{array}{l}\text { Gross Shares } \\
\text { 1992/2011 }\end{array}$} & \multicolumn{2}{|c|}{$\begin{array}{l}\text { Direct Shares } \\
1992 / 2011\end{array}$} & \multicolumn{2}{|c|}{$\begin{array}{l}\text { Total Shares } \\
1992 / 2011\end{array}$} \\
\hline & 0.051 & 0.078 & 0.067 & 0.095 & 0.192 & 0.280 \\
\hline New Zealand & 0.096 & 0.087 & 0.139 & 0.154 & 0.273 & 0.352 \\
\hline China & 0.032 & 0.023 & 0.053 & 0.052 & 0.234 & 0.160 \\
\hline Hong Kong & 0.035 & 0.195 & 0.060 & 0.325 & 0.189 & 0.301 \\
\hline Japan & 0.025 & 0.044 & 0.034 & 0.082 & 0.065 & 0.301 \\
\hline Korea & 0.011 & 0.052 & 0.018 & 0.120 & 0.067 & 0.247 \\
\hline Taiwan & 0.123 & 0.033 & 0.177 & 0.080 & 0.183 & 0.229 \\
\hline Indonesia & 0.033 & 0.026 & 0.049 & 0.033 & 0.082 & 0.081 \\
\hline Malaysia & 0.036 & 0.055 & 0.058 & 0.095 & 0.092 & 0.169 \\
\hline Philippines & 0.128 & 0.071 & 0.245 & 0.115 & 0.194 & 0.149 \\
\hline Singapore & 0.235 & 0.128 & 0.333 & 0.187 & 0.329 & 0.281 \\
\hline Thailand & 0.021 & 0.033 & 0.042 & 0.058 & 0.126 & 0.133 \\
\hline India & 0.069 & 0.165 & 0.111 & 0.307 & 0.176 & 0.309 \\
\hline Rest of South Asia & 0.221 & 0.083 & 0.357 & 0.153 & 0.269 & 0.226 \\
\hline Canada & 0.039 & 0.097 & 0.045 & 0.146 & 0.180 & 0.266 \\
\hline United States & 0.120 & 0.157 & 0.172 & 0.243 & 0.274 & 0.319 \\
\hline Mexico & 0.022 & 0.033 & 0.029 & 0.050 & 0.089 & 0.177 \\
\hline Central America, Caribbean & 0.071 & 0.105 & 0.099 & 0.157 & 0.155 & 0.225 \\
\hline Argentina & 0.089 & 0.066 & 0.132 & 0.121 & 0.165 & 0.210 \\
\hline Brazil & 0.009 & 0.062 & 0.020 & 0.107 & 0.240 & 0.199 \\
\hline Chile & 0.067 & 0.025 & 0.105 & 0.038 & 0.197 & 0.220 \\
\hline Rest of South America & 0.039 & 0.040 & 0.057 & 0.051 & 0.145 & 0.145 \\
\hline EU-3 & 0.155 & 0.118 & 0.209 & 0.201 & 0.280 & 0.378 \\
\hline EU-12 & 0.083 & 0.139 & 0.097 & 0.231 & 0.196 & 0.387 \\
\hline Central European Member States & 0.093 & 0.079 & 0.144 & 0.134 & 0.215 & 0.280 \\
\hline Former Soviet Union & 0.046 & 0.066 & 0.067 & 0.087 & 0.194 & 0.188 \\
\hline Rest of Middle East & 0.041 & 0.076 & 0.043 & 0.081 & 0.097 & 0.132 \\
\hline Sub-Saharan Africa & 0.074 & 0.055 & 0.090 & 0.058 & 0.126 & 0.154 \\
\hline Rest of World & 0.076 & 0.101 & 0.128 & 0.132 & 0.231 & 0.219 \\
\hline Total & 0.090 & 0.096 & 0.127 & 0.155 & 0.224 & 0.271 \\
\hline
\end{tabular}

Notes:

(i) Table shows the share of services exports (without trade and transport) on total exports in 1992 and 2011 for the countries and regions in our sample.

(ii) This is done for exports measured in gross values, direct value added and total value added.

(iii) In the framework of formulas (1-5), and denoting service sectors with $k$ and $l$ and regions with $r$, the export shares of services measured in gross values are $\sum_{k} \hat{\boldsymbol{X}}_{k, l}^{r} / \sum_{i} \sum_{j} \hat{\boldsymbol{X}}_{i, j}^{r}$.

(iv) For the share of services exports measured in direct domestic value added, the formula is $\sum_{k} \hat{\boldsymbol{B}} \hat{\boldsymbol{X}}_{k, l}^{r} /$ $\sum_{i} \sum_{j} \hat{\boldsymbol{B}} \hat{\boldsymbol{X}}_{i, j}^{r}$, and for total value added (forward linkages), it is $\sum_{l} H_{k, l}^{r} / \sum_{i} \sum_{j} H_{i, j}^{r}$.

is due to rising levels of gross trade relative to value added in manufacturing sectors, as shown in Figure 1. There has not been the same roundaboutness for services, though. Accordingly, on a value added basis, services are much more important than on a gross basis, even if for indirect exported value added is not accounted for. Measured in direct exported value added, the share of services exports on total exported value added is about 10 per cent higher in Europe and the United States and about 6 per cent in Singapore. The increase for Hong Kong is even higher, its share of services exports on that basis rises from 19.5 to 32.5 
per cent. India's share of exported services almost doubles when measured in value added compared to gross values. This is also the case for Taiwan, Korea and China, although those countries are still not in the top field of services exporters. Looking over time, developments in value added exports in services reflect those in directly exported services. Services also became less important on a direct value added basis in 2011 compared to 1992 for Singapore, Taiwan, the Philippines and rest of South Asia. On the contrary, this share exploded in Hong Kong and India. Also, the United States and Europe (EU-12) increased their share of value added exports in services by 7 and 13 per cent. Of these countries, only the EU-3 experienced an almost constant share during these two decades.

Adding also indirect exported value added in services increases the importance of services exports, as might be suspected. For Europe, the share of exported services on a total value added basis (forward linkages) increases close to 40 per cent. For the United States, the increase is from 24.3 to almost 32 per cent, and also for Singapore, accounting for indirect exported value added adds 10 per cent to the importance of services exports. Hong Kong and India, however, show a constant and a slightly shrinking share of services exports if also indirect exported value added is accounted for, respectively. This means that for those countries, indirect value added in other sectors is far more important than in the services sectors. The opposite is true for some countries that could not be found in the top list of services exports before. Australia, New Zealand, Japan and the Central European member states, and to a lesser degree also Canada and Korea, jump into the top field of services exporters when they are measured on a total value added base. The share of services exports in this measure in New Zealand even comes close to the one in Western European EU member states. This underlines that despite almost not visible when looking on exports measured in gross values or direct value added, services are clearly a major factor in the total cost structure of these countries.

However, these secret services exporters show a completely different development during our sample period. Also on a total value added basis, Japan and Korea show a very low share of services exports in 1992. Two decades later, these shares ware 4.6 times higher in Japan and 3.7 times higher in Korea. Also Canada and Australia increased their total exports of value added in services considerably during 1992 and 2011. New Zealand, however, was already in 1992 in the top field of services exporters on a total value added basis. The countries we identified also as top exporters of services on a gross value and direct value added basis also experienced a considerable growth of the importance of services exports on a total value added basis. This is especially true for Hong Kong, India and Europe. The increase for the United States was only moderate while the share of services in Singapore decreased when measured in total value added compared to 1992 as it did when measured in gross values and direct value added.

We explore the importance of services exports in exports further by calculating a set of relative intensity indexes. They are based on these sector shares in exports based on total value added (forward linkages) for three services and four non-services sectors and are presented in Table 5. Thus, these indexes provide further insights into the comparative advantage of the different countries on a value added basis. The figures are in line with those presented in Table 4 for services. In general, countries that have their comparative advantage in services are not to be found in the top five in the primary and manufacturing sectors. Exceptions are the EU-3 (Austria, Sweden and Finland), with a high index of total value added exported in other manufacturing and Australia, with a high value in primary products. Besides strong exporters of services on a total value added basis, Singapore and Hong Kong also stand out with their very high comparative advantage as exporters of trade and transport services. But 
TABLE 5

Relative Intensity Indices in 2011

\begin{tabular}{|c|c|c|c|c|c|c|c|}
\hline & Primary & $\begin{array}{l}\text { Text./ } \\
\text { Cloths }\end{array}$ & Machin. & $\begin{array}{l}\text { Oth. } \\
\text { Mfc. }\end{array}$ & $\begin{array}{l}\text { Tradel } \\
\text { Transp. }\end{array}$ & $\begin{array}{l}\text { Com. } \\
\text { Ser. }\end{array}$ & $\begin{array}{l}\text { Pub. } \\
\text { Ser. }\end{array}$ \\
\hline Australia & 0.485 & 0.003 & 0.030 & 0.090 & 0.112 & 0.258 & 0.022 \\
\hline New Zealand & 0.315 & 0.009 & 0.043 & 0.124 & 0.158 & 0.321 & 0.031 \\
\hline China & 0.174 & 0.081 & 0.185 & 0.260 & 0.140 & 0.150 & 0.009 \\
\hline Hong Kong & 0.036 & 0.038 & 0.043 & 0.045 & 0.537 & 0.300 & 0.001 \\
\hline Japan & 0.014 & 0.006 & 0.271 & 0.197 & 0.211 & 0.234 & 0.067 \\
\hline Korea & 0.032 & 0.016 & 0.322 & 0.203 & 0.180 & 0.195 & 0.052 \\
\hline Taiwan & 0.021 & 0.029 & 0.349 & 0.212 & 0.160 & 0.209 & 0.019 \\
\hline Indonesia & 0.471 & 0.068 & 0.065 & 0.203 & 0.112 & 0.076 & 0.005 \\
\hline Malaysia & 0.260 & 0.008 & 0.189 & 0.179 & 0.194 & 0.165 & 0.004 \\
\hline Philippines & 0.210 & 0.032 & 0.317 & 0.136 & 0.154 & 0.141 & 0.008 \\
\hline Singapore & 0.012 & 0.002 & 0.252 & 0.172 & 0.280 & 0.263 & 0.019 \\
\hline Thailand & 0.192 & 0.041 & 0.175 & 0.249 & 0.210 & 0.124 & 0.009 \\
\hline India & 0.218 & 0.052 & 0.045 & 0.182 & 0.194 & 0.302 & 0.007 \\
\hline Rest of South Asia & 0.215 & 0.203 & 0.013 & 0.041 & 0.302 & 0.190 & 0.036 \\
\hline Canada & 0.270 & 0.006 & 0.132 & 0.206 & 0.120 & 0.245 & 0.021 \\
\hline United States & 0.095 & 0.010 & 0.190 & 0.223 & 0.164 & 0.278 & 0.041 \\
\hline Mexico & 0.176 & 0.015 & 0.315 & 0.150 & 0.167 & 0.174 & 0.004 \\
\hline Central America, Caribbean & 0.253 & 0.051 & 0.120 & 0.160 & 0.192 & 0.205 & 0.020 \\
\hline Argentina & 0.457 & 0.008 & 0.064 & 0.130 & 0.131 & 0.192 & 0.018 \\
\hline Brazil & 0.390 & 0.013 & 0.059 & 0.175 & 0.164 & 0.191 & 0.008 \\
\hline Chile & 0.347 & 0.002 & 0.015 & 0.279 & 0.137 & 0.214 & 0.006 \\
\hline Rest of South America & 0.578 & 0.017 & 0.024 & 0.135 & 0.101 & 0.137 & 0.008 \\
\hline EU-3 & 0.071 & 0.013 & 0.173 & 0.254 & 0.111 & 0.358 & 0.019 \\
\hline EU-12 & 0.095 & 0.021 & 0.170 & 0.214 & 0.113 & 0.366 & 0.021 \\
\hline Central European EU & 0.117 & 0.031 & 0.230 & 0.262 & 0.080 & 0.264 & 0.016 \\
\hline Former Soviet Union & 0.457 & 0.005 & 0.030 & 0.113 & 0.208 & 0.181 & 0.007 \\
\hline Rest of Middle East & 0.553 & 0.019 & 0.058 & 0.140 & 0.098 & 0.118 & 0.014 \\
\hline Sub-Saharan Africa & 0.515 & 0.009 & 0.029 & 0.138 & 0.156 & 0.141 & 0.013 \\
\hline Rest of World & 0.355 & 0.035 & 0.080 & 0.147 & 0.163 & 0.192 & 0.027 \\
\hline Total & 0.200 & 0.027 & 0.157 & 0.198 & 0.147 & 0.249 & 0.022 \\
\hline
\end{tabular}

Notes:

(i) Table shows the relative intensity index (based on forward linkages) for seven aggregated sectors for the countries and regions in our sample for the year 2011.

(ii) They are calculated as share of value added embodied in exports of a given sector (based on forward linkages) relative to total value added embodied in a given country's exports, analogue to the calculation in Table 4.

while this makes the economy of Hong Kong extremely dependent on services exports, Singapore also has considerable comparative advantage in machinery and other manufacturing. Finally, while high-income countries and India dominate as commercial services exporters, other developing countries, such as the rest of South Asian region and Thailand are more competitive when it comes to trade and transport services.

\section{SUMMARY}

The service sector accounts for a dominant share of value added in most economies, ranging from 50 to 75 per cent from low to high-income economies (Francois and Hoekman, 
2010). In addition, given the growing share of services exports in total exports, it is becoming increasingly important as a determinant of export competitiveness.

In this paper, we have used different releases of the GTAP database to construct a database of the value added structure of global production and trade covering intermittent years from 1992 to 2011. The resulting data set includes national input-output and cross-border linkages through trade for 29 countries/regions and 24 sectors (with three more sectors for services from 1997 onwards). The data set offers a unique opportunity to examine the value added linkages between services and goods, and the importance of services through these linkages. We analyse not only the direct and indirect contribution of services to value added contained in a given country's exports, but also the extent to which third-country value added in services, through intermediate linkages of imported goods and services, is also embodied in production and trade.

The data indicate that the ratio of value added to gross trade has been decreasing over the last two decades, both for goods and for services, which is consistent with growing vertical production fragmentation. On the other hand, while value added in goods sectors including indirect exports is less than the gross value of exports, in services it is higher than the value of gross exports indicating the importance of services in trade. We also show through a crosssection example that with some notable exceptions, such as India and Singapore, more developed countries generally have more service-intensive exports. Our descriptive tables also indicate that when also taking into account intermediate linkages of imported goods and services, it is apparent that the service sector is critical to the overall cost structure and performance of countries.

\section{REFERENCES}

Baldwin, R. E. (2006), Globalisation: The Great Unbundling(s), Globalisation Challenges for Europe (Helsinki: Prime Minister's Office), 11-54.

Baldwin, R. E. (2014), 'Trade and Industrialisation after Globalisation's Second Unbundling: How Building and Joining a Supply Chain are Different and Why it Matters', in R. C. Feenstra and A. M. Taylor (eds.), Globalization in an Age of Crisis: Multilateral Economic Cooperation in the Twentyfirst Century (Chicago, IL: University of Chicago Press/NBER), 165-212.

Baldwin, R. E. and J. Lopez-Gonzalez (2014), 'Supply-chain Trade: A Portrait of Global Patterns and Several Testable Hypotheses', The World Economy, DOI: 10.1111/twec.12189.

Christen, E. and J. Francois (2015), 'Modes of Supply for US Exports of Services', The World Economy, forthcoming.

Egger, P., J. Francois and D. Nelson (2015), 'The Role of Goods Trade Networks for Services Trade Volume', The World Economy, forthcoming.

Escaith, H. (2008), 'Measuring Trade in Value Added in the New Industrial Economy: Statistical Implications', Paper 14454 (Munich: MPRA).

Francois, J. and B. Hoekman (2010), 'Trade and Policy in Services', Journal of Economic Literature, $48,3,642-92$.

Francois, J. and O. Pindyuk (2010), 'Consolidated Data on International Trade in Services', Discussion Paper (Vienna: WIIW).

Francois, J. and K. Reinert (1996), 'The Role of Services in the Structure of Production and Trade: Stylized Facts from a Cross-country Analysis', Asia-Pacific Economic Review, 2, 1, 1-9.

Francois, J. and J. Woerz (2008), 'Producer Services, Manufacturing Linkages, and Trade', Journal of Industry, Competition and Trade, 8, 3-4, 199-229.

Gehlhar, M.J. (1996), 'Reconciling Bilateral Trade data for Use in GTAP', Technical Paper 1 (Purdue, IN: GTAP).

Hertel, T.W. (2013), 'Global Applied General Equilibrium Analysis Using the Global Trade Analysis Project Framework', in P. Dixon and D. Jorgenson (eds.), Handbook of Computable General Equilibrium Modeling (North Holland: Elsevier), 815-76. 
Inklaar, R., M. Timmer and B. van Ark (2008), 'Market Services Productivity Across Europe and the US', Economic Policy, 23, 1, 139-94.

Johnson, R. C. and G. Noguera (2012a), 'Accounting for Intermediates: Production Sharing and Trade in Value Added', Journal of International Economics, 86, 2, 224-36.

Johnson, R. C. and G. Noguera (2012b), 'Fragmentation and Trade in Value Added Over Four Decades', Working Paper 18186 (Cambridge, MA: National Bureau of Economic Research).

McDougall, R. (ed.) (2001), The GTAP Database, Version 5. (Purdue, IN: Purdue University).

McDougall, R. and J. Hagemejer (2005), 'Services Trade Data', in Dimaranan B. and R. McDougall (eds.), Global Trade, Assistance, and Production: The GTAP 6 Data Base, Center for Global Trade Analysis (Purdue, IN: Purdue University), 1-18.

Park, S. and K. Chan (1989), 'A Cross-country Input-output Analysis of Intersectoral Relationships between Manufacturing and Services', World Development, 17, 2, 199-212.

Uno, K. (1989), Measurement of Services in an Input-output Framework (Amsterdam: Elsevier Science).

Van Leeuwen, N. and A. Lejour (2006), 'Bilateral Services Trade Data and the GTAP Database', CPB Memorandum 160 (The Hague: Central Planning Bureau).

World Trade Organization (2009), International Trade Statistics (Geneva: WTO). 
APPENDIX

TABLE A1

Value Added Content of Trade Globally

\begin{tabular}{|c|c|c|c|c|c|c|c|}
\hline & 1992 & 1995 & 1997 & 2001 & 2004 & 2007 & 2011 \\
\hline \multicolumn{8}{|l|}{ All trade } \\
\hline $\begin{array}{l}\text { Gross exports relative to gross output } \\
\text { value }\end{array}$ & 0.082 & 0.110 & 0.119 & 0.122 & 0.132 & 0.142 & 0.133 \\
\hline $\begin{array}{l}\text { Exports of direct VA relative to global } \\
\text { GDP }\end{array}$ & 0.064 & 0.085 & 0.085 & 0.086 & 0.092 & 0.101 & .094 \\
\hline $\begin{array}{l}\text { Exports of total VA relative to global } \\
\text { GDP }\end{array}$ & 0.061 & 0.078 & 0.080 & 0.082 & 0.089 & 0.195 & .189 \\
\hline Gross exports relative to global GDP & 151 & 208 & 221 & 0.228 & .250 & 0.274 & 0.262 \\
\hline $\begin{array}{l}\text { Exports of direct VA relative to gross } \\
\text { exports }\end{array}$ & & & 386 & 0.375 & 366 & 368 & 360 \\
\hline $\begin{array}{l}\text { Exports of total VA relative to gross } \\
\text { exports }\end{array}$ & 0.830 & 0.783 & 0.748 & 0.735 & 0.723 & 0.711 & 0.723 \\
\hline \multicolumn{8}{|l|}{ Agriculture and processed food } \\
\hline $\begin{array}{l}\text { Gross exports relative to gross output } \\
\text { value }\end{array}$ & 0.058 & 0.091 & 0.094 & 0.096 & 118 & 0.115 & 0.120 \\
\hline $\begin{array}{l}\text { Exports of direct VA relative to total VA } \\
\text { in final sales }\end{array}$ & 0.059 & 0.090 & 0.089 & 0.092 & 0.110 & 0.105 & 0.108 \\
\hline $\begin{array}{l}\text { Exports of total VA relative to total VA in } \\
\text { final sales }\end{array}$ & 0.117 & 0.172 & 171 & 0.186 & .221 & .218 & .225 \\
\hline $\begin{array}{l}\text { Gross exports relative to total VA in final } \\
\text { sales }\end{array}$ & 0.150 & 0.233 & 0.241 & 0.247 & 0.297 & 0.288 & 0.284 \\
\hline $\begin{array}{l}\text { Exports of direct VA relative to gross } \\
\text { exports }\end{array}$ & 0.395 & 0.387 & 0.369 & 0.370 & 0.371 & 0.366 & 0.380 \\
\hline $\begin{array}{l}\text { Exports of total VA relative to gross } \\
\text { exports }\end{array}$ & 0.781 & 0.741 & 710 & 53 & 744 & 0.756 & 0.793 \\
\hline \multicolumn{8}{|l|}{ Energy and mining } \\
\hline $\begin{array}{l}\text { Gross exports relative to gross output } \\
\text { value }\end{array}$ & 0.120 & 0.192 & 0.244 & 0.233 & 0.279 & 0.297 & 0.344 \\
\hline $\begin{array}{l}\text { Exports of direct VA relative to total VA } \\
\text { in final sales }\end{array}$ & 0.133 & 0.221 & 0.289 & 0.291 & 0.384 & 0.413 & 0.469 \\
\hline $\begin{array}{l}\text { Exports of total VA relative to total VA in } \\
\text { final sales }\end{array}$ & 0.288 & 0.399 & 0.480 & 0.520 & 0.615 & 0.644 & 0.718 \\
\hline $\begin{array}{l}\text { Gross exports relative to total VA in final } \\
\text { sales }\end{array}$ & 0.312 & 0.484 & 0.635 & 0.669 & 0.779 & 0.854 & 0.961 \\
\hline $\begin{array}{l}\text { Exports of direct VA relative to gross } \\
\text { exports }\end{array}$ & 0.425 & 0.456 & 0.455 & 0.436 & 0.493 & 0.484 & 0.488 \\
\hline $\begin{array}{l}\text { Exports of total VA relative to gross } \\
\text { exports }\end{array}$ & 0.925 & 0.823 & 0.756 & 0.777 & 0.790 & 0.754 & 0.747 \\
\hline \multicolumn{8}{|l|}{ Textiles, clothing, leather } \\
\hline $\begin{array}{l}\text { Gross exports relative to gross output } \\
\text { value }\end{array}$ & 0.186 & 0.254 & 0.287 & 0.300 & 0.345 & 0.317 & 0.293 \\
\hline $\begin{array}{l}\text { Exports of direct VA relative to total VA } \\
\text { in final sales }\end{array}$ & 0.174 & 0.241 & 0.275 & 0.295 & 0.348 & 0.317 & 0.293 \\
\hline $\begin{array}{l}\text { Exports of total VA relative to total VA in } \\
\text { final sales }\end{array}$ & 0.251 & 0.338 & 0.385 & 0.433 & 0.488 & 0.463 & 0.442 \\
\hline $\begin{array}{l}\text { Gross exports relative to total VA in final } \\
\text { sales }\end{array}$ & 37 & 99 & 935 & 1.018 & .224 & 1.139 & .098 \\
\hline
\end{tabular}


TABLE A1 Continued

\begin{tabular}{|c|c|c|c|c|c|c|c|}
\hline & 1992 & 1995 & 1997 & 2001 & 2004 & 2007 & 2011 \\
\hline $\begin{array}{l}\text { Exports of direct VA relative to gross } \\
\text { exports }\end{array}$ & 0.296 & 0.298 & 0.294 & 0.290 & 0.284 & 0.279 & 0.267 \\
\hline $\begin{array}{l}\text { Exports of total VA relative to gross } \\
\text { exports }\end{array}$ & 0.427 & 0.417 & 0.412 & 0.426 & 0.399 & 0.407 & 0.402 \\
\hline \multicolumn{8}{|l|}{ Chemicals } \\
\hline $\begin{array}{l}\text { Gross exports relative to gross output } \\
\text { value }\end{array}$ & 0.150 & 0.215 & 0.238 & 0.260 & 0.335 & 0.345 & 0.323 \\
\hline $\begin{array}{l}\text { Exports of direct VA relative to total VA } \\
\text { in final sales }\end{array}$ & 0.154 & 0.222 & 0.241 & 0.259 & 0.355 & 0.367 & $0.34 \mathrm{C}$ \\
\hline $\begin{array}{l}\text { Exports of total VA relative to total VA in } \\
\text { final sales }\end{array}$ & 0.300 & 0.388 & 0.415 & 0.434 & 0.532 & 0.546 & 0.539 \\
\hline $\begin{array}{l}\text { Gross exports relative to total VA in final } \\
\text { sales }\end{array}$ & 0.507 & 0.641 & 0.763 & 0.843 & 1.131 & 1.216 & 1.145 \\
\hline $\begin{array}{l}\text { Exports of direct VA relative to gross } \\
\text { exports }\end{array}$ & 0.304 & 0.346 & 0.316 & 0.307 & 0.314 & 0.302 & 0.305 \\
\hline $\begin{array}{l}\text { Exports of total VA relative to gross } \\
\text { exports }\end{array}$ & 0.591 & 0.604 & 0.543 & 0.515 & 0.470 & 0.449 & 0.471 \\
\hline \multicolumn{8}{|l|}{ Metals } \\
\hline $\begin{array}{l}\text { Gross exports relative to gross output } \\
\text { value }\end{array}$ & 0.103 & 0.160 & 0.186 & 0.186 & 0.221 & 0.258 & 0.235 \\
\hline $\begin{array}{l}\text { Exports of direct VA relative to total VA } \\
\text { in final sales }\end{array}$ & 0.096 & 0.149 & 0.175 & 0.170 & 0.214 & 0.254 & 0.241 \\
\hline $\begin{array}{l}\text { Exports of total VA relative to total VA in } \\
\text { final sales }\end{array}$ & 0.260 & 0.343 & 0.407 & 0.410 & .473 & 0.504 & 0.496 \\
\hline $\begin{array}{l}\text { Gross exports relative to total VA in final } \\
\text { sales }\end{array}$ & 0.313 & 0.489 & 0.616 & 0.635 & 0.736 & 0.912 & 0.874 \\
\hline $\begin{array}{l}\text { Exports of direct VA relative to gross } \\
\text { exports }\end{array}$ & 0.306 & 0.304 & 0.284 & 0.268 & 0.291 & 0.279 & 0.276 \\
\hline $\begin{array}{l}\text { Exports of total VA relative to gross } \\
\text { exports }\end{array}$ & 0.828 & 0.702 & 0.660 & 0.645 & 0.642 & 0.553 & 0.567 \\
\hline \multicolumn{8}{|l|}{ Transport equipment } \\
\hline $\begin{array}{l}\text { Gross exports relative to gross output } \\
\text { value }\end{array}$ & 0.252 & 0.280 & 0.303 & 0.335 & 0.377 & 0.378 & 0.338 \\
\hline $\begin{array}{l}\text { Exports of direct VA relative to total VA } \\
\text { in final sales }\end{array}$ & 0.257 & 0.274 & 0.297 & 0.329 & 0.381 & 0.385 & 0.352 \\
\hline $\begin{array}{l}\text { Exports of total VA relative to total VA in } \\
\text { final sales }\end{array}$ & 0.294 & 0.331 & 0.388 & 0.424 & 0.497 & 0.503 & 0.468 \\
\hline $\begin{array}{l}\text { Gross exports relative to total VA in final } \\
\text { sales }\end{array}$ & 0.726 & 0.885 & 1.117 & 1.250 & 1.542 & 1.558 & 1.471 \\
\hline $\begin{array}{l}\text { Exports of direct VA relative to gross } \\
\text { exports }\end{array}$ & 0.355 & 0.309 & 0.266 & 0.263 & 0.247 & 0.247 & 0.239 \\
\hline $\begin{array}{l}\text { Exports of total VA relative to gross } \\
\text { exports }\end{array}$ & 0.405 & 0.374 & 0.347 & 0.339 & 0.323 & 0.323 & 0.318 \\
\hline \multicolumn{8}{|l|}{ Other machinery } \\
\hline $\begin{array}{l}\text { Gross exports relative to gross output } \\
\text { value }\end{array}$ & 0.271 & 0.366 & 0.417 & 0.426 & 0.421 & 0.416 & 0.389 \\
\hline $\begin{array}{l}\text { Exports of direct VA relative to total VA } \\
\text { in final sales }\end{array}$ & 0.267 & 0.361 & 0.406 & 0.408 & 0.422 & 0.422 & 0.405 \\
\hline $\begin{array}{l}\text { Exports of total VA relative to total VA in } \\
\text { final sales }\end{array}$ & 0.334 & 0.441 & 0.503 & 0.507 & 0.547 & 0.551 & 0.540 \\
\hline
\end{tabular}


TABLE A1 Continued

\begin{tabular}{|c|c|c|c|c|c|c|c|}
\hline & 1992 & 1995 & 1997 & 2001 & 2004 & 2007 & 2011 \\
\hline $\begin{array}{l}\text { Gross exports relative to total VA in final } \\
\text { sales }\end{array}$ & 0.676 & 0.927 & 1.170 & 1.217 & 1.395 & 1.394 & 1.396 \\
\hline $\begin{array}{l}\text { Exports of direct VA relative to gross } \\
\text { exports }\end{array}$ & 0.395 & 0.390 & 0.347 & 0.335 & 0.303 & 0.303 & 0.290 \\
\hline $\begin{array}{l}\text { Exports of total VA relative to gross } \\
\text { exports }\end{array}$ & 0.494 & 0.476 & 0.430 & 0.416 & 0.392 & 0.395 & 0.386 \\
\hline \multicolumn{8}{|l|}{ Rest of manufactures } \\
\hline $\begin{array}{l}\text { Gross exports relative to gross output } \\
\text { value }\end{array}$ & 0.122 & 0.164 & 0.170 & 0.186 & 0.186 & 0.190 & 0.165 \\
\hline $\begin{array}{l}\text { Exports of direct VA relative to total VA } \\
\text { in final sales }\end{array}$ & 0.120 & 0.160 & 0.160 & 0.175 & 0.179 & 0.184 & 0.166 \\
\hline $\begin{array}{l}\text { Exports of total VA relative to total VA in } \\
\text { final sales }\end{array}$ & 0.211 & 0.271 & 0.279 & 0.297 & 0.313 & 0.326 & 0.298 \\
\hline $\begin{array}{l}\text { Gross exports relative to total VA in final } \\
\text { sales }\end{array}$ & 0.319 & 0.434 & 0.460 & 0.500 & 0.505 & 0.523 & 0.479 \\
\hline $\begin{array}{l}\text { Exports of direct VA relative to gross } \\
\text { exports }\end{array}$ & 0.377 & 0.369 & 0.347 & 0.350 & 0.355 & 0.352 & 0.347 \\
\hline $\begin{array}{l}\text { Exports of total VA relative to gross } \\
\text { exports }\end{array}$ & 0.662 & 0.625 & 0.607 & 0.595 & .620 & 0.623 & 0.623 \\
\hline \multicolumn{8}{|l|}{ Electricity, gas, water } \\
\hline $\begin{array}{l}\text { Gross exports relative to gross output } \\
\text { value }\end{array}$ & 0.002 & 0.005 & 0.021 & 0.020 & 0.020 & 0.027 & 0.024 \\
\hline $\begin{array}{l}\text { Exports of direct VA relative to total VA } \\
\text { in final sales }\end{array}$ & 0.003 & 0.005 & 0.021 & 0.020 & .022 & 0.029 & .026 \\
\hline $\begin{array}{l}\text { Exports of total VA relative to total VA in } \\
\text { final sales }\end{array}$ & 0.122 & 0.161 & 0.212 & 0.233 & 0.249 & 0.265 & 0.255 \\
\hline $\begin{array}{l}\text { Gross exports relative to total VA in final } \\
\text { sales }\end{array}$ & 0.005 & 0.011 & 0.048 & 0.041 & 0.043 & 0.063 & 0.055 \\
\hline $\begin{array}{l}\text { Exports of direct VA relative to gross } \\
\text { exports }\end{array}$ & 0.566 & 0.521 & 0.436 & 0.486 & 0.502 & 0.455 & 0.468 \\
\hline $\begin{array}{l}\text { Exports of total VA relative to gross } \\
\text { exports }^{a}\end{array}$ & 24.042 & 15.295 & 4.440 & 5.742 & 5.736 & 4.186 & 4.663 \\
\hline \multicolumn{8}{|l|}{ Construction } \\
\hline $\begin{array}{l}\text { Gross exports relative to gross output } \\
\text { value }\end{array}$ & 0.002 & 0.006 & 0.009 & 0.007 & 0.008 & 0.011 & 0.009 \\
\hline $\begin{array}{l}\text { Exports of direct VA relative to total VA } \\
\text { in final sales }\end{array}$ & 0.002 & 0.006 & 0.009 & 0.007 & 0.008 & 0.011 & 0.009 \\
\hline $\begin{array}{l}\text { Exports of total VA relative to total VA in } \\
\text { final sales }\end{array}$ & 0.015 & 0.027 & 0.032 & 0.029 & 0.035 & 0.038 & 0.038 \\
\hline $\begin{array}{l}\text { Gross exports relative to total VA in final } \\
\text { sales }\end{array}$ & 0.005 & 0.014 & 0.021 & 0.016 & 0.019 & 0.026 & 0.022 \\
\hline $\begin{array}{l}\text { Exports of direct VA relative to gross } \\
\text { exports }\end{array}$ & 0.392 & 0.405 & 0.422 & 0.413 & 0.425 & 0.418 & 0.412 \\
\hline $\begin{array}{l}\text { Exports of total VA relative to gross } \\
\text { exports }\end{array}$ & 2.957 & 1.976 & 1.482 & 1.833 & 1.863 & 1.472 & 1.678 \\
\hline \multicolumn{8}{|l|}{ Trade and transport services } \\
\hline $\begin{array}{l}\text { Gross exports relative to gross output } \\
\text { value }\end{array}$ & 0.069 & 0.084 & 0.078 & 0.076 & 0.086 & 0.094 & 0.082 \\
\hline $\begin{array}{l}\text { Exports of direct VA relative to total VA } \\
\text { in final sales }\end{array}$ & 0.071 & 0.083 & 0.077 & 0.072 & 0.076 & 0.082 & 0.074 \\
\hline
\end{tabular}


TABLE A1 Continued

\begin{tabular}{|c|c|c|c|c|c|c|c|}
\hline & 1992 & 1995 & 1997 & 2001 & 2004 & 2007 & 2011 \\
\hline $\begin{array}{l}\text { Exports of total VA relative to total VA in } \\
\text { final sales }\end{array}$ & 0.136 & 0.172 & 0.172 & 0.170 & 0.186 & 0.199 & 0.192 \\
\hline $\begin{array}{l}\text { Gross exports relative to total VA in final } \\
\text { sales }\end{array}$ & 0.116 & 0.148 & 0.140 & 0.138 & 0.174 & 0.194 & 0.163 \\
\hline $\begin{array}{l}\text { Exports of direct VA relative to gross } \\
\text { exports }\end{array}$ & 0.609 & 0.565 & 0.551 & 0.522 & 0.436 & 0.425 & 0.451 \\
\hline $\begin{array}{l}\text { Exports of total VA relative to gross } \\
\text { exports }\end{array}$ & 1.174 & 1.161 & 1.221 & 1.234 & 1.068 & 1.028 & 1.177 \\
\hline \multicolumn{8}{|l|}{ Other commercial services } \\
\hline $\begin{array}{l}\text { Gross exports relative to gross output } \\
\text { value }\end{array}$ & 0.025 & 0.023 & 0.034 & 0.038 & 0.040 & 0.048 & 0.05 \\
\hline $\begin{array}{l}\text { Exports of direct VA relative to total VA } \\
\text { in final sales }\end{array}$ & 0.029 & 0.024 & 0.036 & 0.040 & 0.043 & 0.051 & 0.055 \\
\hline $\begin{array}{l}\text { Exports of total VA relative to total VA in } \\
\text { final sales }\end{array}$ & 0.098 & 0.117 & 0.133 & 0.139 & 0.156 & 0.168 & 0.187 \\
\hline $\begin{array}{l}\text { Gross exports relative to total VA in final } \\
\text { sales }\end{array}$ & 0.047 & 0.046 & 0.063 & 0.071 & 0.076 & 0.092 & 0.094 \\
\hline $\begin{array}{l}\text { Exports of direct VA relative to gross } \\
\text { exports }\end{array}$ & 0.618 & 0.525 & 0.574 & 0.565 & 0.564 & 0.558 & 0.587 \\
\hline $\begin{array}{l}\text { Exports of total VA relative to gross } \\
\text { exports }\end{array}$ & 2.083 & 2.552 & 2.099 & 1.957 & 2.039 & 1.829 & 1.976 \\
\hline \multicolumn{8}{|l|}{ Public services } \\
\hline $\begin{array}{l}\text { Gross exports relative to gross output } \\
\text { value }\end{array}$ & 0.006 & 0.026 & 0.017 & 0.016 & 0.014 & 0.014 & 0.011 \\
\hline $\begin{array}{l}\text { Exports of direct VA relative to total VA } \\
\text { in final sales }\end{array}$ & 0.006 & 0.025 & 0.017 & 0.016 & 0.014 & 0.014 & 0.011 \\
\hline $\begin{array}{l}\text { Exports of total VA relative to total VA in } \\
\text { final sales }\end{array}$ & 0.013 & 0.043 & 0.035 & 0.031 & 0.028 & 0.028 & 0.025 \\
\hline $\begin{array}{l}\text { Gross exports relative to total VA in final } \\
\text { sales }\end{array}$ & 0.008 & 0.038 & 0.024 & 0.022 & 0.020 & 0.020 & 0.016 \\
\hline $\begin{array}{l}\text { Exports of direct VA relative to gross } \\
\text { exports }\end{array}$ & 0.695 & 0.651 & 0.705 & 0.720 & 0.683 & 0.681 & 0.680 \\
\hline $\begin{array}{l}\text { Exports of total VA relative to gross } \\
\text { exports }\end{array}$ & 1.569 & 1.139 & 1.463 & 1.433 & 1.390 & 1.390 & 1.553 \\
\hline
\end{tabular}

Notes:

(i) The gross values of exports in utilities are close to zero in the data set.

(ii) This causes the ratio of the total exported VA to gross exports to explode.

(iii) ${ }^{a}$ The gross values of exports in utilities are close to zero in the dataset. This causes the ratio of the total exported VA to gross exports to explode. 
TABLE A2

Sector Shares of Gross Exports - World Trade

\begin{tabular}{|c|c|c|c|c|c|c|c|}
\hline & 1992 & 1995 & 1997 & 2001 & 2004 & 2007 & 2011 \\
\hline Agr., forestry, fisheries & 0.041 & 0.034 & 0.029 & 0.026 & 0.023 & 0.021 & 0.027 \\
\hline Processed food & 0.031 & 0.042 & 0.038 & 0.035 & 0.036 & 0.034 & 0.042 \\
\hline Energy extraction & 0.079 & 0.053 & 0.062 & 0.058 & 0.086 & 0.114 & 0.096 \\
\hline Minerals nec & 0.017 & 0.014 & 0.006 & 0.005 & 0.010 & 0.013 & 0.020 \\
\hline Beverages, tobacco & 0.008 & 0.007 & 0.008 & 0.007 & 0.007 & 0.007 & 0.007 \\
\hline Textiles & 0.027 & 0.026 & 0.030 & 0.028 & 0.025 & 0.020 & 0.022 \\
\hline Wearing apparel & 0.028 & 0.027 & 0.022 & 0.022 & 0.019 & 0.016 & 0.017 \\
\hline Leather products & 0.014 & 0.014 & 0.012 & 0.013 & 0.010 & 0.009 & 0.009 \\
\hline Wood products & 0.016 & 0.017 & 0.017 & 0.017 & 0.016 & 0.015 & 0.013 \\
\hline Paper, publishing & 0.022 & 0.025 & 0.021 & 0.021 & 0.018 & 0.016 & 0.016 \\
\hline Chemicals, rubber, plastic & 0.082 & 0.097 & 0.093 & 0.099 & 0.111 & 0.109 & 0.125 \\
\hline Mineral products & 0.009 & 0.011 & 0.016 & 0.016 & 0.010 & 0.010 & 0.010 \\
\hline Ferrous metals & 0.022 & 0.028 & 0.023 & 0.020 & 0.024 & 0.027 & 0.026 \\
\hline Metals nec & 0.016 & 0.018 & 0.024 & 0.022 & 0.024 & 0.031 & 0.037 \\
\hline Metal products & 0.016 & 0.018 & 0.018 & 0.018 & 0.018 & 0.019 & 0.020 \\
\hline Transport equipment & 0.090 & 0.090 & 0.095 & 0.103 & 0.107 & 0.099 & 0.094 \\
\hline Machinery, equipment nec & 0.219 & 0.242 & 0.257 & 0.257 & 0.235 & 0.214 & 0.216 \\
\hline Manufactures nec & 0.026 & 0.023 & 0.022 & 0.026 & 0.017 & 0.017 & 0.018 \\
\hline Construction & 0.002 & 0.004 & 0.006 & 0.004 & 0.004 & 0.006 & 0.005 \\
\hline Electricity, gas, water & 0.001 & 0.001 & 0.004 & 0.004 & 0.004 & 0.005 & 0.004 \\
\hline Trade and transport & 0.147 & 0.129 & 0.111 & 0.103 & 0.098 & 0.096 & 0.090 \\
\hline Other commercial services & 0.080 & 0.056 & 0.073 & 0.082 & 0.085 & 0.092 & 0.077 \\
\hline Public services & 0.007 & 0.023 & 0.015 & 0.015 & 0.014 & 0.012 & 0.010 \\
\hline Dwellings & 0.000 & 0.000 & 0.000 & 0.000 & 0.000 & 0.000 & 0.000 \\
\hline Total & 1.000 & 1.000 & 1.000 & 1.000 & 1.000 & 1.000 & 1.000 \\
\hline \multicolumn{8}{|l|}{ Extended service sectors } \\
\hline Trade & n.a. & n.a. & 0.020 & 0.025 & 0.022 & 0.020 & 0.017 \\
\hline Transport & n.a. & n.a. & 0.090 & 0.078 & 0.076 & 0.076 & 0.073 \\
\hline Communication & n.a. & n.a. & 0.005 & 0.006 & 0.006 & 0.006 & 0.005 \\
\hline Financial services & n.a. & n.a. & 0.006 & 0.008 & 0.011 & 0.014 & 0.012 \\
\hline Insurance & n.a. & n.a. & 0.006 & 0.006 & 0.008 & 0.008 & 0.006 \\
\hline Business services & n.a. & n.a. & 0.045 & 0.051 & 0.050 & 0.054 & 0.045 \\
\hline Recreation, other services & n.a. & n.a. & 0.011 & 0.012 & 0.010 & 0.009 & 0.008 \\
\hline Public services & n.a. & n.a. & 0.015 & 0.015 & 0.014 & 0.012 & 0.010 \\
\hline Total services & n.a. & n.a. & 0.203 & 0.203 & 0.201 & 0.205 & 0.181 \\
\hline
\end{tabular}

Note:

In the Table, we relate exports of a sector to world trade valued at gross values. 